DOI https://doi.org/10.30525/978-9934-26-109-1-33

\title{
АНАЛІЗ ЗАКОНОДАВЧИХ ЗМІН У СФЕРІ ЗЕМЛЕУСТРОЮ, КАДАСТРУ ТА МІСТОБУДУВАННЯ ПІД ЧАС ФОРМУВАННЯ ТА ВИКОРИСТАННЯ ТЕРИТОРІЙ ОБ'ЄДНАНИХ ГРОМАД
}

\author{
Пілічева М. О. \\ кандидат технічних наук, доцент, \\ доцент кафедри земельного адміністрування \\ та геоінформачійних систем \\ Харківський національний університет міського господарства \\ імені О. М. Бекетова \\ м. Харків, Украӥна \\ Анопріснко Т. В. \\ кандидат економічних наук \\ Харківський національний аграрний університет \\ імені В. В. Докучаєва \\ м. Харків, Украӥна \\ Маслій Л. О. \\ Харківський наџіональний університет міського господарства \\ імені О. М. Бекетова \\ м. Харків, Украӥна
}

Адміністративно-територіальна реформа в Україні проводиться 3 2015 року. Ї̈і основною метою є децентралізація влади - передача значних повноважень і коштів від центральних органів влади органам місцевого самоврядування, а також зміна адміністративнотериторіального поділу. Замість понад 11000 місцевих рад сформовано 1469 об’єднаних територіальних громад [1].

Формування територіальних громад здійснюється згідно Методики формування спроможних територіальних громад [2], зміни до якої були внесені 24 січня 2020 р., у такій послідовності: визначаються потенційні адміністративні центри спроможних територіальних громад та зон їх доступності; встановлюється перелік територіальних громад, що входять до складу спроможних територіальних громад; проводиться оцінка рівня спроможності. 
При цьому облдержадміністрація розробляє із залученням представників органів місцевого самоврядування, органів самоорганізації населення та громадськості відповідних адміністративнотериторіальних одиниць проект перспективного плану території об'єднаної громади в електронному та паперовому вигляді, який відображає межі громад, їх потенційні адміністративні центри та всі населені пункти, що увійшли до їх складу.

Межі території спроможної територіальної громади визначаються по зовнішніх межах юрисдикції рад територіальних громад, що входять до ії складу, з дотриманням наступних вимог:

- територія повинна включати території територіальних громад, що входять до ії складу, та бути нерозривною;

- розташовуються у межах території однієї області;

- у разі входження до складу спроможної територіальної громади однієї або кількох територіальних громад, розташованих на території суміжного району, розширенню підлягають межі району, на території якого розташований адміністративний центр утвореної спроможної територіальної громади.

Також розробляються паспорти спроможних територіальних громад.

До травня 2021 року питання визначення меж територій громад на місцевості та реєстрації їх у Державному земельному кадастрі не було законодавчо врегульовано. Для усунення цієї прогалини були прийнято зміни до законодавчих актів України у сфері землеустрою та кадастру [3]. Згідно прийнятого Закону [3] для з'ясування дійсної межі території громади розробляються проекти землеустрою щодо встановлення меж територій територіальних громад, де наводиться опис меж території; креслення меж території громади, складене у відповідному масштабі та каталог координат поворотних точок меж. Відомості про межі території територіальної громади вносяться до Державного земельного кадастру та зазначаються у витягу 3 Державного земельного кадастру, який безоплатно видається відповідній сільській, селищній, міській раді. При цьому до Державного земельного кадастру включаються такі відомості про землі в межах території територіальної громади [3]: найменування громади; опис іiі меж; площа земель у іiі межах; найменування суміжних територіальних громад; інформація про матеріали, на підставі яких встановлені (змінені) межі території громади.

Також відбулися зміни і у сфері планування використання земель, яка тісно пов'язана 3 веденням Державного земельного та 
містобудівного кадастрів [4]. 3 серпня 2021 року з'явиться особливий вид документації - комплексні плани просторового розвитку територій територіальних громад, та змінять статус генеральні плани населених пунктів і детальні плани територій, які будуть одночасно документацією із землеустрою та містобудівною документацією на місцевому рівні [5].

Комплексний план просторового розвитку території територіальної громади, генеральний план населеного пункту, крім відомостей, передбачених Законом України «Про регулювання містобудівної діяльності», повинен включати [5]:

- матеріали топографо-геодезичних вишукувань;

- матеріали погодження відповідно до Земельного кодексу України;

- експлікацію земельних угідь за власниками та користувачами земельних ділянок;

- переліки обмежень у використанні земель та переліки земельних ділянок, щодо яких встановлено обмеження у використанні земель;

- збірний план земельних ділянок, наданих у власність чи користування, та земельних ділянок, не наданих у власність чи користування;

- план розподілу земель за категоріями, власниками i користувачами (форма власності, вид речового права), угіддями 3 відображенням наявних обмежень (обтяжень).

Детальний план території додатково повинен містити переліки обмежень у використанні земель та переліки земельних ділянок, щодо яких встановлено обмеження у використанні земель.

Формування земельних ділянок комунальної власності територіальної громади та внесення до Державного земельного кадастру відомостей про земельні ділянки всіх форм власності, сформованих до 2004 року, відомості про які відсутні у Державному земельному кадастрі, може виконуватися під час розробки комплексного плану просторового розвитку території територіальної громади, генерального плану населеного пункту, детального плану території. При цьому до такої документації включаються:

- відомості про обчислення площі земельної ділянки;

- кадастровий план земельної ділянки;

- матеріали перенесення меж земельної ділянки в натуру (на місцевість);

- перелік обмежень у використанні земельних ділянок; 
- акт приймання-передачі межових знаків на зберігання;

- акт перенесення в натуру (на місцевість) меж охоронних зон, зон санітарної охорони, санітарно-захисних зон і зон особливого режиму використання земель (за наявності).

Відомості про сформовані земельні ділянки та обмеження у використанні земель (територій), визначені комплексним планом просторового розвитку території територіальної громади, генеральним планом населеного пункту, детальним планом території, підлягають внесенню до містобудівного та Державного земельного кадастрів.

Комплексний план повинен містити просторові дані, метадані та інші елементи, що складають його проектні рішення, i буде розробляється у формі електронного документа, що відповідає вимогам базового набору геопросторових даних [6]. Він підписується кваліфікованими електронними підписами відповідальних осіб, які його розробили, - архітектор, який має відповідний кваліфікаційний сертифікат, та сертифікований інженер-землевпорядник.

Отже, сучасні зміни законодавства у сфері земельних відносин та територіального планування встановлюють нові види документації із землеустрою та містобудування при формуванні та використанні території громади та визначають тісний зв'язок між відомостями Державного земельного та містобудівного кадастрів.

\section{Література:}

1. Адміністративно-територіальний устрій України. Офіційний сайт. URL: https://atu.decentralization.gov.ua/ (дата звернення: 28.06.2021).

2. Про затвердження Методики формування спроможних територіальних громад: Постанова Кабінету Міністрів України від 8 квітня 2015 p. № 214 / Верховна Рада України. URL: https://zakon.rada.gov.ua/laws/show/214-2015-\%D0\%BF\#Text (дата звернення: 28.06.2021).

3. Про внесення змін до деяких законодавчих актів України щодо вдосконалення системи управління та дерегуляції у сфері земельних відносин: Закон України від 28 квітня 2021 року № 1423-IX / Верховна Рада України. URL: https://zakon.rada.gov.ua/laws/show/ 1423-20\#Техt (дата звернення: 28.06.2021).

4. Кошкалда I. В., Анопрієнко Т. В., Пілічева М. О. Використання містобудівної документації під час здійснення землеустрою та ведення кадастрів. International scientific and practical conference 
«Science, engineering and technology: global and current trends». December 27-28, 2019. Prague. P. 126-129.

5. Про внесення змін до деяких законодавчих актів України щодо планування використання земель: Закон України від 17 червня 2020 року № 711-IX / Верховна Рада України. URL: https://zakon.rada. gov.ua/laws/show/711-20\#Text (дата звернення: 28.06.2021).

6. Пілічева М. О., Кінь Д. О., Поморцева О. Є. Інтеграція топографічної і кадастрової інформації базового набору геопросторових даних земельної ділянки. Містобудування та територіальне планування. 2018. № 66. С. 523-531. 